\title{
The Comforting Nonsense of Creativity
}

\author{
Mark Readman \\ Faculty of Media and Communication, University of Bournemouth, UK \\ Correspondence: mreadman@bournemouth.ac.uk \\ ORCID: https://orcid.org/0000-0003-0463-5663
}

Peer review: This article has been subject to a double-blind peer review process

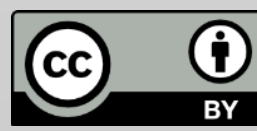

Copyright notice: This article is issued under the terms of the Creative Commons Attribution License, which permits use and redistribution of the work provided that the original author and source are credited.

You must give appropriate credit (author attribution), provide a link to the license, and indicate if changes were made. You may do so in any reasonable manner, but not in any way that suggests the licensor endorses you or your use. You may not apply legal terms or technological measures that legally restrict others from doing anything the license permits.

https://creativecommons .org/licenses/by/4.0/

\begin{abstract}
Jonah Lehrer's book Imagine: How Creativity Works was discredited when it was discovered that it included fabricated quotes by Bob Dylan. It was also criticised for cherry picking the science of creativity and adding little of worth to the literature on the subject.

While this may be true, I suggest that much scientific literature about creativity is already epistemologically and methodologically incoherent, and characterised by the treatment of creativity as something with stable ontic status, rather than something which is always, inevitably produced through cultural processes of interpretation and association. An examination, using the tools of discourse analysis, of some of the research papers cited by Lehrer, along with other related examples, reveals some of the assumptions and rhetorical manoeuvres at work.

Despite the overt falsehoods in his book, the stories that Jonah Lehrer tells us are consistent with the stories that the research, science, and policy tell us about creativity - all are equally fanciful. Nevertheless, if we choose to suspend our disbelief in such stories, and their rhetorical prestidigitation, there are some comforts and pleasures to be obtained from the illusion of essential humanity that they create.
\end{abstract}

Keywords: Creativity; Jonah Lehrer; Discourse; Neuroscience; Stories; Consolations 


\section{The Disgrace of Jonah Lehrer (and why he was already wrong about creativity)}

In 2012 the journalist Jonah Lehrer resigned from his post at the New Yorker after admitting that he fabricated quotes from Bob Dylan in his book Imagine: How Creativity Works. His deception was exposed by the journalist Michael Moynihan who, keen to track down the sources for seven of the Dylan quotes (Ulaby, 2012), ended up getting Lehrer to confess that the quotes 'either did not exist, were unintentional misquotations, or represented improper combinations of previously existing quotes' (Myers, 2012). But prior to this Lehrer's book, despite debuting -at the top of the New York Times non-fiction bestseller list (Holpuch, 2012) had already been criticised for its uncritical faith in neuroscience to reveal the mysteries of creativity. Steven Poole, for example indicts Lehrer for his 'neuroscientism': '[the] promise that brainscans (using the limited current technologies of $\mathrm{fMRI}$ and EEG) can explain the workings of the mind' (Poole, 2012). There are two key points in Poole's scathing review which, I think, are useful charges against Lehrer, but also the general field of 'creativity research'. The first pertains specifically to neuroscience: 'The inconvenient truth is that observing which areas of the brain light up on a screen during experiment tells us little about "how creativity works"'; the second is applicable more widely:

The larger problem...is the sheer variety of activities that Lehrer has conflated without argument as representing "creativity" or "imagination". The composition of a song or poem is just assumed to be the same sort of thing as the solving of a hoary riddle or word-puzzle by experimental volunteers in a magnetic-resonance-imaging tube, or the dreaming-up of new moves in surfing, or the copying of a German porn doll to market it as Barbie, or the invention of a new kind of mop (Poole, 2012).

It is this tendency to conflate disparate things - attributes, artefacts, practices - which is characteristic not just of Lehrer's book, but of research into creativity more generally; the things which are drawn into the frame are so diverse and contradictory, so produced by assumptions and prejudices about art, craft, problem solving, agency, and thinking itself, that it is often difficult to identify what is not 'creative'. My argument, then, is not that Lehrer does science a disservice by (as Poole puts it in a later article) 'cherry picking results and distorting their implications' and by telling 'simple stories sprinkled with cutting-edge science' (Poole, 2016) but that the field of creativity research is already nothing more than a set of more or less nonsensical stories about the origins of the human capacity for invention. We can explore this by following Foucault's example when he suggests that: 
The problem does not consist in drawing the line between that in a discourse which falls under that category of scientificity or truth, and that which comes under some other category, but in seeing historically how effects of truth are produced within discourses which in themselves are neither true nor false (Foucault, 1984: 60).

It is important, then, to recognise that science does not take place in a hygienic realm, free from the contaminants of language and culture (see, for example, Popper, 2002; Latour \& Woolgar, 1986; Doyle, 2017). In the field of creativity research there are some distinctive discursive traits which produce and reproduce particular notions of creativity, by which I mean not just ways of speaking and writing about creativity, but ways of constructing it through particular procedures and conditions. A focus on language, discourse and rhetoric enables us to describe 'creativity' as a construction rather than a 'thing' with ontic stability anchored in the real world; just as Richard Rorty suggests that philosophy is a kind of writing (Rorty, 1978: 143) creativity, too, is built upon metaphorical representations of the relationship between mind and body, and signs and referents. Creativity, in this light, becomes a mythical construction like 'love', 'violence' or 'national identity'. And like love, national identity, and maybe even violence, it offers some reassuring ideas about who we are and our place in the world; like all fairy tales, there is no reality here, but there are potential pleasures, nonetheless. Lehrer's book, then, is a conveniently paradoxical place from which to launch a critique of the science of creativity; Lehrer may have included actual falsehoods but these tend to mask the more widespread misconceptions in the field of creativity research which it faithfully (if excitedly) reports.

In what follows I argue for an approach to creativity which focuses on language and discourse; then for the need to interrogate the assumptions underlying the procedures of creativity research, using some of Lehrer's examples; next, the ways in which research correlates art and creativity; and finally the ways in which a 'science of the creative city' lends itself to myth-making in policy. I conclude by suggesting that Lehrer's work is entirely consistent with the myth-making of creativity research - none of it is 'true', but by suspending our disbelief it enables us to indulge in comforting fantasies about human exceptionalism.

\section{An Anti-ontology of Creativity}

A focus on the discourse and rhetoric of creativity is a modest, but radical strategy - radical because it destabilises the notion that creativity is a thing with independent existence. Banaji et al. (2006), for example, recognise the discursive dimension of creativity and, with great economy, they identify a range of different, often contradictory, versions of the concept. 
The choice of the word rhetoric, with its connotations of philosophy and literary analysis is telling, as is their use of the plural - a simple, but profound indicator that creativity is not a unitary entity or concept. They elaborate:

By rhetorics we mean in this context a subset of discourse, characterised by specific properties:

- They are highly elaborated structures, drawing on distinctive traditions of philosophical, educational, political and psychological thought

- They are organised to persuade as a form of 'communicative action'...seeking to bring about consensus, leading in some cases to intervention in specific contexts of practice

- They produce discursive frameworks such as key terms and taxonomies which can be learnt by practitioners who either need them or are obliged to use them. In this way they feed back into more general 'popular' discourses of creativity (Banaji et al., 2006: 5)

The groundwork is created here for an 'anti-ontology' of creativity, and an invitation to engage with a 'poetics' of creativity. The authors, however, hold back on the anti-ontology, often asking 'is...?' questions about creativity which, I have argued before, reveals a dependence upon an essential premise - that 'it' exists and that there is a real phenomenon, quality or attribute which is called 'creativity' (Readman, 2010: 18).

We might consider, instead, that creativity is not an object which researchers have 'discovered', but that it is an arbitrary labelling of a range of different behaviours and processes. By refusing to accept the existence of creativity as a starting point, and by analysing the language used to describe and account for it, we can, I think, reveal the nature of the poetics and argue that there is little with tangible status there at all. This more radical stance mobilises a Foucaultian approach to discourse which, according to Kendall and Wickham, begins by 'the recognition of a discourse as a corpus of 'statements' whose organisation is regular and systematic' (Kendall \& Wickham, 1999: 42) and entails the recognition that 'statements involve 'things' as well as 'words'. They counsel that 'The crucial thing here is to avoid the idea that [discourse] is a purely linguistic term (as in most incarnations of 'discourse analysis')' (Kendall \& Wickham, 1999: 35). To illustrate how this strategy might be useful we could look, for example, at the way in which experimental science produces creativity discursively, not only through its language and arguments expressed in academic papers, but through the tools which it has devised in order to identify the object of study, such as Functional Magnetic Resonance Imaging (fMRI), the electroencephalogram (EEG), and the administration 
of these tests in laboratory conditions. These processes are implicated in the language and arguments, and they also inform the language and arguments. Showing how creativity becomes discursively active as a concept entails locating it within particular contexts and identifying how these contexts create the conditions for creativity to be manifested in a particular way. And discourse, as a concept, enables us to see the relationships between rhetorical enunciation and power; power, that is, as a force by which meaning is asserted - through language, institutions and operations.

\section{Scientism and Creativity}

An examination of some of the experiments that Jonah Lehrer discusses certainly reveals a degree of 'cherry picking', but also shows how the experiments themselves reify creativity as something tangible. The rationale for experimental approaches to creativity proposed by Mark Runco and Shawn Sakamoto illuminates how this process of reification works:

Creativity is among the most complex of human behaviours. It seems to be influenced by a wide array of developmental, social, and educational experiences, and it manifests itself in different ways in a variety of domains. The highest achievements in the arts are characterized by their creativity, as are those in the sciences. Creativity is also quite common in a wide range of everyday activities.

They infer, therefore, that:

The complex nature of creativity suggests that meaningful research must take multiple influences and diverse forms of expression into account. Experimental research on creativity is useful precisely for this reason. Experimental methods utilize various controls to reduce complexity to a manageable level (Runco \& Sakamoto, 1999: 62)

The experimental method works on the basis that a complex phenomenon can be broken down into its component parts, each part understood, then reassembled and thereby, the whole understood. This method legitimises the kinds of laboratory experiments described by Lehrer, such as Mark Jung-Beeman's work on insight (Lehrer, 2012: 8-19). Jung-Beeman et al., actually mention the noun 'creativity' just once - in the introduction when they say that insight occurs in 'various forms of practical, artistic, and scientific creativity' and the adjective once when they say that 'Performance on insight problems is associated with creative thinking...' (Jung-Beeman et al., 2004: 0500). 
This 'argument by association' is typical in the creativity literature and is a very common feature in Lehrer's book, in which he cuts back and forth between the experimental work on insight and his narrative about Bob Dylan rediscovering his mojo, arguing that Dylan's 'uncontrollable rush of a creative insight' (Lehrer, 2012: 19) exemplifies the 'Aha!' moments sought in Jung-Beeman et al.'s study. It is not just the association implied through contiguity in the book which creates this sense of unity, but also the adjective 'creative' which is used to modify or augment 'insight' in the quote above. In addition, we learn from Jung-Beeman et al. that the anterior superior temporal gyrus in the right hemisphere of the brain is 'the most likely area to contribute to this component of insight problem solving' (2004: 0501) and, consequently, Lehrer reports confidently that 'During those first frantic minutes of writing, [Dylan's] right hemisphere found a way to make something new out of this incongruous list of influences' (Lehrer, 2012: 21). But this is not to say that Lehrer is alone in creating myths; Jung-Beeman et al. use the story of Archimedes to provide a model for the kind of insight that is sought in their experimental work and, although it is referred to as a 'legend' (0500) it is the notion of the 'Eureka!' moment which underpins the work and the article. As the article progresses, the legendary status of the Archimedes story recedes until by the end it is discussed as if it were historical fact:

In the two millennia since Archimedes shouted "Eureka!", it has seemed common knowledge that people sometimes solve problems - whether great scientific questions or trivial puzzles - by a seemingly distinct mechanism called insight (Jung-Beeman et al., 2004: 0507).

Curiously no other specific examples of the 'Eureka!' moment are adduced (despite the 'two millennia' of opportunity), so Archimedes is offered as the ideal subject to represent the subjective experience of insight, just as for Jonah Lehrer Bob Dylan is the ideal subject to exemplify his breakthrough when writing 'Like a Rolling Stone' (Lehrer, 2012: 19-24). This work on insight, which is connected tangentially to creativity, reveals some of the associative rhetoric at work. We can also see a process of reification at work, that is, an attempt to make the invisible and intangible into something concrete. The experiment is an attempt to identify, in the brain, particular 'events' and to see if they 'are as sudden as the subjective experience (Jung-Beeman et al., 2004: 0506) and, because the subjective experience of 'sudden insight' has been rhetorically linked with creativity, it is possible for Lehrer to argue that 'a flicker of electricity inside the head' (2012: 19) can be precisely located. 


\section{The Seductions of Correlation, or: How science makes sense of art}

Scientific experiments into creativity tend to be characterised in following way: a 'phenomenon' (say, musical improvisation) is identified and its essential ('creative') nature is assumed to be evident, which then justifies an investigation into its cause. What often follows is a rhetorical shift from identifying correlation to generating aetiological theory - in other words, an activity which is categorised as 'creative' is correlated with neurological, psychological, sociological events, and causes are inferred.

But the 'creative' activity observed is the result of an act of interpretation - its nature is inferred because there is already a culturally acquired investment in what creativity is supposed to be. In the well-known case of Tommy McHugh, for example, a builder who suffered a subarachnoid haemorrhage and subsequently became obsessed with producing sculptures and paintings the researchers infer that this kind of production represents 'artistic creativity':

He drew hundreds of sketches, mainly of faces, all of them asymmetric. This was followed by large-scale drawings on the walls of his house sometimes covering whole rooms. He claims the brain injury has left him obsessed with making art and he now spends most of his day painting and sculpting (Lythgoe et al., 2005: 397)

When these researchers looked at Tommy McHugh, they saw a man making up poems, crafting clay sculptures and painting, all of which were assumed to be markers of creativity. But they could equally have been markers of compulsive behaviour. Here, then, the products of the compulsive production have been judged as more significant than the compulsion itself. And, perhaps unsurprisingly for neuroscientists, the perceived breakthrough here is believed to be the insight into a specific brain mechanism of creativity:

The emergence of artistic skills following subarachnoid haemorrhage may represent another platform into the mechanisms of artistic creativity and an unrecognized attribute of this type of brain injury (Lythgoe et al., 2005: 398)

Discursively, this work contributes to a pathological model of creativity which is persuasive because it opens up the possibility of 'prescription' as a result of 'diagnosis', in other words, if the causes can be diagnosed then it might be possible to create the conditions for the non-pathological to 'be creative' (a kind of 'reverse cure'). But there is a tension here, and at its heart is the question of agency; if one is compelled to 'be creative' then what is the status of that process? When Noël Carroll (1999), for example, 
employs a philosophical approach to defining the work of art, the intention of the artist to create an aesthetic experience is always present in some form. Similarly, Anthony Storr's psychoanalytically grounded exploration of creative drive and motive resists the idea that '...the artist is a man who can only achieve satisfaction for his instinctual drives in phantasy...' (Storr, 1972: 17). This seems to be at the root of Lehrer's fetishisation of 'science' as opposed to any particular model of brain, body or context; he flirts with pathology, only to reveal possible ways of 'hacking' oneself in order to be creative. There are obvious, similar attractions to computational paradigms for the brain (see, for example, Boden, 2014).

Lehrer discusses a range of cases of frontotemporal dementia - a disease of the prefrontal cortex (and, incidentally, the primary point of comparison for Mark Lythgoe and his colleagues in the case of Tommy McHugh):

These patients are suddenly overcome with the desire to paint and draw and sculpt. They lose interest in everything else. Then, after they have a few precious years of ecstatic productivity, the disease that inspired their art destroys their brains (Lehrer, 2012: 106).

Again, the output here is unproblematically categorised as 'art', and by implication 'creative', because it includes painting, drawing and sculpture. And from this pathological context he presents us with a 'hack' - a way of 'silencing temporarily' (as opposed to destroying) the dorsolateral prefrontal cortex via repetitive transcranial magnetic stimulation (rTMS). This 'hack' is presented in the work of Allan Snyder whose paper cited here is titled 'Savant-like skills exposed in normal people by suppressing the left fronto-temporal lobe' (Snyder et al., 2003). The paper uses the word 'creativity' only once, in the keywords, although Lehrer (presumably quoting an interview rather than the paper) tells us that Snyder refers to TMS (Lehrer omits the ' $r$ ') as a "creativity amplifying machine", and refers to the "creativity treatment" that he administers to his subjects (Lehrer, 2012: 109). There is a speculative model of the brain underpinning this research - that of the 'modular brain', which comprises distinct areas with discrete functions. The modular brain is a seductive idea because it provides a way of breaking down complex behaviours into more manageable ones, and when activity in a particular area of the brain correlates with particular human activity it excites scientists with the promise of causality.

Snyder et al. begin with the phenomenon of 'the astonishing skills of savants' and speculate that they are 'latent in everyone'. The focus on drawing skills is significant in this experiment, as it elides 'artistic skills' with 'savant-like skills', and the tensions between wholly cultural assessments of artistic products and the scientific method emerge in this statement: 
In order to ensure objectivity, a committee first inspected all of the drawings (arranged in random order) to judge them for the "best" art. This did not lead to any consensus... however, a subsequent committee was asked to judge whether drawings... within any series showed a demonstrable change of scheme or convention. This led unambiguously to the sets we present here. Ratings by raters who are blind to the order of the drawings is a standard method of psychological evaluation (Snyder et al., 2003: 151).

The rhetoric of assertion is evident here - the need to persuade us of objectivity, of standard methods, of the validity of judgements based on randomised elements and of the expertise of an anonymous 'committee'. For Lehrer, this scientific method is proof positive that by suppressing the left fronto-temporal lobe one can release one's inner artist:

Before subjects are treated with TMS, most of their drawings are crude stick figures that don't look very much like anything. However, after people receive their "creativity treatment", their drawings are often transformed; the figures are suddenly filled with artistic flourishes. (Lehrer, 2012: 109).

Through a rhetorical sleight of hand in Snyder et al. 'creativity' emerges from 'artistry', which in turn emerges from 'savantism'. And the 'modular brain' also comes into focus as a legitimate, uncontested paradigm, despite evidence that it is a site of debate; see for example, Patricia Churchland who argues that '...any neuronal business of any significant complexity is underpinned by spatially distributed networks, and not just incidentally, but essentially' (Churchland, 2015: 286), and Matthew Cobb who talks about '...the mistaken impression that our brains are composed of anatomically distinct modules' (Cobb, 2020). Just as Lehrer fetishises science, there are scientists who fetishise the brain, which is not to say that the brain is insignificant - as Raymond Tallis says: "Chop my head off and my IQ descends" (Parry, 2011) - but that the quest for a specific location for 'creativity' is always a narrative freighted with particular assumptions, tools and desires.

\section{Stories from the (Creative) City}

The second half of Lehrer's book is sociological rather than neuroscientific. One might assume that the methodological and epistemological contradictions between such diverse studies might be problematic, but 'creativity' is an amorphous concept and incredibly absorbent. Lehrer's strategy is consistent - to assert that he is adducing scientific evidence of 'how creativity works'. When describing research into urban innovation he focuses on the character of Geoffrey West who 'likes to compare himself 
to Kepler, Galileo, and Newton, since he's also a theoretical physicist in search of fundamental laws' and '...he wanted his advice to be wholly empirical, rooted in the strictness of facts. West was tired of urban theory - he wanted to invent urban science' (Lehrer, 2012: 184-185). It is ironic that West dismisses modern urban theory as 'storytelling' without 'rigour' given the ways in which Lehrer constructs him as the hero of this particular story (West's co-authors don't get a mention, apart from the first author of the cited paper, Luis Bettencourt - 'another physicist who had given up on physics') and the ways in which the scientific process is described. Interestingly, as with some of the other papers discussed here, Bettencourt et al. only mention 'creativity' once:

We believe that the further extension and quantification of urban scaling relations will provide a unique window into the spontaneous social organization and dynamics that underlie much of human creativity, prosperity, and resource demands on the environment (Bettencourt et al., 2007: 7306).

Perhaps realising that 'creativity', the noun, is a potential hostage to fortune, the emphasis is on the factors underlying creativity; rhetorically this adjectival hedging is not an uncommon strategy. Another feature is the use of the proxy 'innovation', a word which is less problematic, and often allied with creativity. For Lehrer, the implied revelations are sufficient for him to use the research to provide insights into 'the most creative cities'. The obvious seduction of this work for Lehrer is the scientific method - cities are rendered as data, patterns are discerned and represented graphically, and outputs such as 'wealth and knowledge creation' are measured statistically (knowledge creation in the form of new patents, that is). He is particularly enthusiastic about a physics metaphor, which somehow becomes a literal explanation for how cities generate new ideas:

They compare urban residents to particles with velocity bouncing off one another and careening in unexpected directions. The most creative cities are simply the ones with the most collisions (Lehrer, 2012: 190).

It is this evocation of the scientific discourse which creates the illusion of unity between work on urban growth and the earlier chapters on 'creativity centres' in the brain. In addition, the poetry of cities creating 'sparks' and 'collisions' suggests that the brain and the city might be more than metaphorically related, and that in some respects they operate in the same way.

And what this masks, of course, is the accommodation of a neoliberal mobilisation of the idea of 'creativity' - something popularised by Richard Florida (not mentioned by Lehrer, perhaps because the work lacks the 
necessary 'scientific heft') along with his concept of a 'creative class'. This is built upon (perhaps paradoxically) a notion of romantic individualism and 'people's intrinsic motivations' (Florida, 2002: 101), despite his entreaty in the final chapter for the creative class to:

Evolve from an amorphous group of self-directed, albeit high-achieving, individuals into a more cohesive, more responsible group (Florida, 2002: 316).

The promise of wealth and knowledge creation, along with urban regeneration has led to an uncritical embrace of the 'creative class' and Florida's book, as Oli Mould points out '...is used to justify continued inward investment and gentrification, as long as it looks creative' (Mould, 2018: 24).

What creativity looks like, in this context, probably conforms to something like the UK Department of Culture Media and Sport's mapping document for the creative industries, which includes: advertising; architecture; art and antiques markets; crafts; design; designer fashion; film and video; interactive leisure software; music; performing arts; publishing; software and computer services; and television and radio (DCMS, 2001). As an arbitrary category - a container for a range of economic activities more or less engaged in the production of cultural artefacts - this might work, but as the foreword, written by then Culture Secretary, Chris Smith, makes clear, there is a morality, perhaps even a spirit being mobilised here:

Our creative industries [...] are a real success story, and a key element in today's knowledge economy. All of this is, of course, founded on original creativity - the lifeblood of these industries... I want all young people to have the opportunity to express and channel their creativity through a wide range of activities, including for some a career in the creative industries... I want all businesses to think creatively, to realise creativity is not an add-on but an essential ingredient for success. (DCMS, 2001).

Creativity, here then, is more than an expedient means of categorising a range of industries - these industries, supposedly, capture some kind of essence of this quality (a pro-social quality which provides opportunity, enrichment and profit). This is why a later report by the British Council revealed how some workers in these industries cavilled at the inclusion of others - they believed that some industries were genuinely creative, whereas others were merely present by association with something more noble: 
The presence of the antiques trade on the DCMS list has also been challenged, on the grounds that there is no fresh act of creation involved, merely the retail of pre-existing ones (British Council, 2010: 18).

What Jonah Lehrer does in Imagine is not very different from what creativity research, science and policy like this inevitably does: it elides differences between a range of internal and external activities; it seeks an essence; it uses assertion; it creates felicitous associations upon which are built more robust assertions; it attempts to reify the intangible and make visible the invisible; it infers the existence of creativity from associated phenomena; it produces 'creativity' through rhetorical and discursive means, which include the poetic invocations of spirit and selfdetermination as well as the moves of power constituted by authoritative citation and the construction of subjects.

Let's consider, finally, how all this nonsense might be comforting.

\section{The Consolations of Creativity: Suspending one's disbelief}

The creativity literature is a vast sprawling field which encompasses many disciplines and, as in Lehrer's book, the epistemological and methodological contradictions are somehow subordinated to the promise of insight, self-actualisation and economic growth.

Some recent work, however, offers a necessary critical intervention. Angela McRobbie, for example, adopts a Foucaultian stance and argues that creativity has become something '...which has the potential to be turned into a set of capacities. The resulting assemblage of 'talent' can subsequently be unrolled in the labour market or "talent-led economy". She develops the notion of the 'creativity dispositif' which 'comprises various instrument, guides, manuals, devices, toolkits, mentoring schemes, reports, TV programmes and other forms of entertainment' and which constitute a form of 'governmentality (McRobbie, 2016: 22). McRobbie uses this notion of governmentality to explain how young people might embrace precarity and construct themselves as neoliberal subjects - to become active agents in their own exploitation.

Similarly, Oli Mould argues that 'creativity has become a straitjacket, a character trait that fuels the further imposition of that very same [individualistic] narrative. Sure, everyone is creative, but only those who have 'made it' (those with the privilege) have the luxury of profiting from that creativity' (Mould, 2018: 159).

Andreas Reckwitz, like McRobbie, in Foulcaultian mode, carries out detailed genealogical work in order to present the historical cultural 'invention' of creativity. He suggests, though, that 'we should not make a 
blanket declaration of war on the aesthetic and the regimes of novelty and audience, because we would then run the risk of moral fundamentalism, anti-modern conservatism, or the idyll of the private self', and advocates, instead, 'strategies for the self-containment of the aesthetic and of the regimes of novelty and the audience' (Reckwitz, 2017: 235).

Whereas Mould ends with a battle cry, to reclaim 'creativity' as a radical, revolutionary act, Reckwitz's response is more modest - a withdrawal rather than a charge - but both ask us to reject the cant.

Perhaps a third way is detached indulgence - a suspension of disbelief. In Gareth Tunley's film The Ghoul (2016) the psychotherapist Morland played by Geoff McGivern encourages his troubled patient to make his depression tangible:

A lot of what I do is trying to distract you, rather like a stage magician. Only the rabbit I'm trying to pull from the hat is the solution to your depression... when a magician raises a demon or an angel it may only be real in his head, but if it's real to him it may as well be real, full stop. If he makes it into something tangible then he can deal with what it represents. It's the process that matters (The Ghoul, 2016).

This is not so much a leap of faith as a willingness to be duped - an awareness that there will be some benefits from allowing the fantasy to exist. And creativity is a pleasurable fantasy, as Mould points out, parodying Richard Florida's thesis: "we are all creative; we just need to 'unleash' that creativity on the world (Mould, 2018: 25).

In a recent episode of BBC Radio 4's arts programme Front Row, the presenter John Wilson asks his guest, George the Poet:

We're hearing a lot at the moment about this lockdown stimulating creativity and people tapping into skills that possibly they'd forgotten about, or never even tried before. How has it affected you? Have you found yourself writing more at home? What effect has it had on your own personal creativity?

George the poet replies:

A message to anyone out there that feels pressure to be suddenly amazing: a lot of what you are going to deliver is already within you, and sometimes it's the case of you just being still, being in the moment, just accepting the situation and then allowing the creativity to flow (Front Row, 2020).

There is a hydraulic metaphor at work here - the figure of creativity as a liquid force within the body, which needs to be 'tapped' or released in order to flow. It is the metaphor favoured by creativity theorist Mihaly 
Csikszentmihalyi (1996) which conjures up a semi-conscious state of losing oneself in an activity. It recalls the 'lifeblood' metaphor which, incidentally, is one of the BBC's stated values: "Creativity is the lifeblood of our organisation" (BBC 2020). And it is a particularly seductive metaphor at a time when people's freedoms are restricted, and the notion of human exceptionalism is undermined. To believe that self-expression is an index of something which makes us more than merely potential hosts for a virus is appealing, even if we have few illusions about the quality of that selfexpression.

This link between human exceptionalism and creativity is made explicit in Kazuo Ishiguro's novel Never Let Me Go (2005) in which we meet a group of friends at boarding school. We learn that creativity is valued highly and that the students are urged to paint, draw and sculpt, but we aren't sure what's at stake in this. We hear that 'There'd been no real change in Tommy's work - his reputation for 'creativity' was as low as ever' (22) but that one of the teachers had 'known a lot of students...who'd for a long time found it very difficult to be creative: painting, drawing, poetry, none of it going right for years. Then one day they'd turned a corner and blossomed' (27). It's not until later that we learn that the students are clones, reared for organ donation, and that their creativity is nurtured by the benevolent school as proof of their humanity; as one of the teachers says: 'We took away your art because we thought it would reveal your souls. Or to put it more finely, we did it to prove you had souls at all (255). There is a germ of something recognisable in this grotesque dystopian fantasy; sensitivity, soulfulness, spirituality, authenticity, humanity, are all terms which circulate around notions of creativity. As George the Poet implies, one's essential, inner self is revealed through the 'flow' of creativity.

Jonah Lehrer's Imagine: How Creativity Works may be tainted by the inclusion of some made-up Bob Dylan quotes, but even if they were genuine the book would be no more or less authoritative; it tells us stories about research which is already founded on and which perpetuates myths about 'creativity', so seeking a distinction between that which is 'true' and that which is 'false' seems like a rather quaint and artificial binary. One reviewer, perhaps with a sense of this, argued for the book's rehabilitation, regardless of the author's sins, because, he said, 'it worked for me' (Clark, 2012).

The book does not do a disservice to the 'science of creativity', because the bulk of the creativity literature is already smoke and mirrors. The concept of creativity is constituted through the activation of particular tropes which make sense of, and mobilise, a whole range of disparate, real activities and processes. Some of these activities and processes are 
internal and cognitive, some are external and practical, but in a range of very different contexts - scientific, pedagogic, spiritual and artistic for example - they are all nominated as 'creative', and as a result of this nominalisation these processes and activities become meaningful, valuable, connected and useful or applicable.

Mark Readman is principal academic in media education in the Faculty of Media and Communication at Bournemouth University, and editor of the Media Education Research Journal. His research is underpinned by an interest in rhetoric and discourse and how these produce 'truths' about the social world; much of his work has examined the concept of 'creativity' as a discursive construction. He is also the editor of Teaching and Learning On Screen - a collection of essays which examine how myths about education are produced in film and on television.

\section{References}

BBC Mission, values and public purposes. Available at:

https://www.bbc.com/aboutthebbc/governance/mission, [Accessed 5 May 2020].

Front Row, 2020. BBC Radio 4, 7 May 2020.

Bettencourt, L. M. A., Lobo, J., Helbing, D., Kühnert, C. \& West, G. B., 2007. Growth, innovation, scaling, and the pace of life in cities. PNAS, 104(17), pp.7301-7306.

Boden, M., 2014. Creativity and Artificial Intelligence: A contradiction in terms? In: Paul, E. S. \& Kaufman, S. B., eds., The Philosophy of Creativity. Oxford: Oxford University Press, pp. 224-244.

Bosman, J., 2012. Jonah Lehrer resigns from The New Yorker after making up Dylan quotes for his book. The New York Times, 30 July 2012. Available at: https://mediadecoder.blogs.nytimes.com/2012/07/30/jonah-lehrer-resignsfrom-new-yorker-after-making-up-dylan-quotes-for-his-book/, [Accessed 1 May 2020].

British Council, 2010. Mapping the Creative industries: A toolkit. London: British Council.

Carroll, N., 1999. Philosophy of Art. London: Routledge.

Churchland, P. S., 2015. Brain Modules. In: Brockman, J., ed., This Idea Must Die. New York: Harper Collins, pp.286-287. 
Clark R. P., 2012. Why Jonah Lehrer's 'Imagine' is worth reading, despite the problems. Poynter, 14 September 2012. Available at:

https://www.poynter.org/reporting-editing/2012/why-jonah-lehrers-imagineis-worth-reading-despite-the-problems/, [Accessed 1 September 2020].

Cobb, M., 2020. The Idea of the Brain. London: Profile Books Ltd. (epub).

Csikszentmihalyi, M., 1996. Creativity: Flow and the Psychology of Discovery and Invention. New York: Harper Collins.

DCMS, 2001. Creative industries mapping document. London: DCMS.

Doyle, R., 2017. Rhetoric and Science. In: MacDonald, M. J., ed., The Oxford Handbook of Rhetorical Studies. Oxford: Oxford University Press, pp.745-758.

Florida, R., 2002. The rise of the creative class. New York: Basic Books.

Foucault, M., 1984. Truth and power. In Rabinow, P. ed., The Foucault Reader. London: Penguin, pp.51-75.

Holpuch, A., 2012. Jonah Lehrer quits New Yorker after admitting he made up Dylan quotes. The Guardian, 30 July 2012. Available at:

https://www.theguardian.com/media/us-news-blog/2012/jul/30/jonah-lehrerquits-new-yorker, [Accessed 5 May 2020].

Ishiguro, K., 2005. Never Let Me Go. London: Faber and Faber.

Jung-Beeman, M., Bowden, E. M., Haberman, J., Frymiare, J. L., Arambel-Liu, S., Greenblatt, R., Reber, P. J. \& Kounios, J., 2004. Neural Activity When People Solve Verbal Problems with Insight. Biology, 2(4), pp.0500-0510.

Kendall, G. \& Wickham, G., 1999. Using Foucault's Methods. London: Sage.

Latour, B. \& Woolgar, S., Laboratory Life: The Construction of Scientific Facts. Princeton: Princeton University Press.

Lehrer, J., 2012. Imagine: How Creativity Works. New York: Houghton Mifflin Harcourt.

Lythgoe, M. F. X., Pollak, T. A., Kalmus, M., deHaan, M. \& Chong, W. K., 2005. Obsessive, prolific artistic output following subarachnoid hemorrhage.

Neurology, 64, pp.397-398.

McRobbie, A., 2016. Be Creative: Making a living in the creative industries. Cambridge: Polity.

Mould, O., 2018. Against Creativity. London: Verso.

Myers, S., 2012. Journalist feels 'horrible' about revealing Jonah Lehrer's fabrications. Poynter. 30 July 2012. Available at:

https://www. poynter.org/reporting-editing/2012/journalist-feels-horribleabout-revealing-jonah-lehrers-fabrications/, [Accessed: 1 May 2020].

NACCCE, 1999. All Our Futures: Creativity, Culture and Education. London: DCMS. 
Parry, M., 2011. Raymond Tallis Takes Out the 'Neurotrash'. The Chronicle of Higher Education. 9 October 2011. Available at:

https://www.chronicle.com/article/Raymond-Tallis-Takes-Out-the/129279, [Accessed: 1 May 2020].

Poole, S., 2012. Imagine: How Creativity Works by Jonah Lehrer review. The Guardian. 19 April 2012. Available at:

https://www.theguardian.com/books/2012/apr/19/imagine-creativity-jonahlehrer-review, [Accessed: 29 April 2020].

Poole, S., 2016. Don't call it a comeback: has Jonah Lehrer plagiarised again? The Guardian. 13 July 2016. Available at:

https://www.theguardian.com/books/booksblog/2016/jul/13/ionah-lehrerplagiarism-accusations-a-book-about-love, [Accessed: 1 May 2020].

Popper, K., 2002, The logic of scientific discovery. Abingdon: Routledge.

Readman, M., 2010. What's in a Word? The Discursive Construction of 'Creativity'. PhD. Bournemouth University.

Reckwitz, A., 2017. The Invention of Creativity. Cambridge: Polity Press.

Rorty, R., 1978. Philosophy as a kind of writing: An essay on Derrida. New Literary History, 10(1), pp.141-160.

Runco, M. A. \& Sakamoto, S. O.,1999. Experimental studies of creativity. In: Sternberg, R. J., ed., Handbook of Creativity. New York: Cambridge University Press, pp. 62-92.

Snyder, A., Mulchahy, E., Taylor, J. L., Mitchell, D. J., Sachdev, P. \& Gandevia, S. C., 2003. Savant-like skills exposed in normal people by suppressing the left fronto-temporal lobe. Journal of Integrative Neuroscience, 2(2), pp.149-158.

Sternberg, R. J. \& Davidson, J. E., eds., 1995. The Nature of Insight. Cambridge, Mass.: MIT Press.

Storr, A., 1972. The Dynamics of Creation. London: Penguin.

Ulaby, N. (2012). 'The Lies Are Over': A Journalist Unravels. npr. 31 July 2012. Available at: https://www.npr.org/2012/07/31/157654005/the-lies-are-over-ajournalist-unravels?t=1589817533616, [Accessed: 2 May 2020].

\section{To cite this article:}

Readman, M. 2020. The comforting nonsense of creativity. Exchanges: The Interdisciplinary Research Journal, 8(1), 40-56. Available at: https://doi.org/10.31273/eiri.v8i1.651. 